
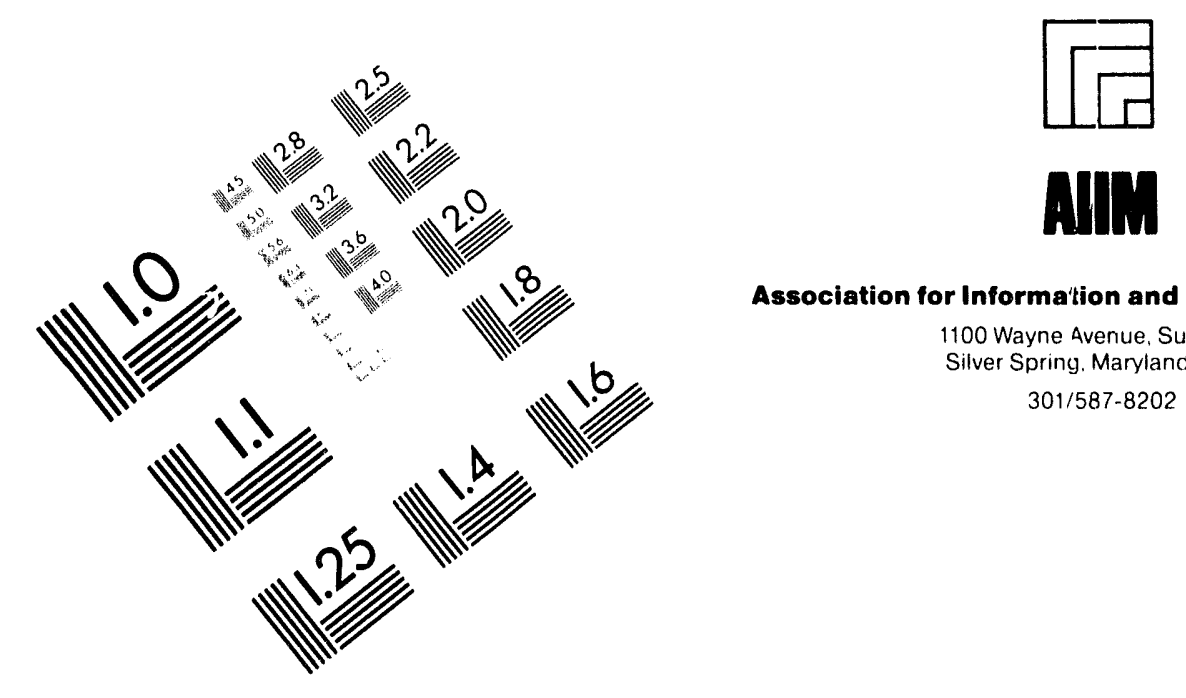

Association for Information and Image Management

1100 Wayne Avenue, Suite 1100

Silver Spring. Maryland 20910

301/587-8202

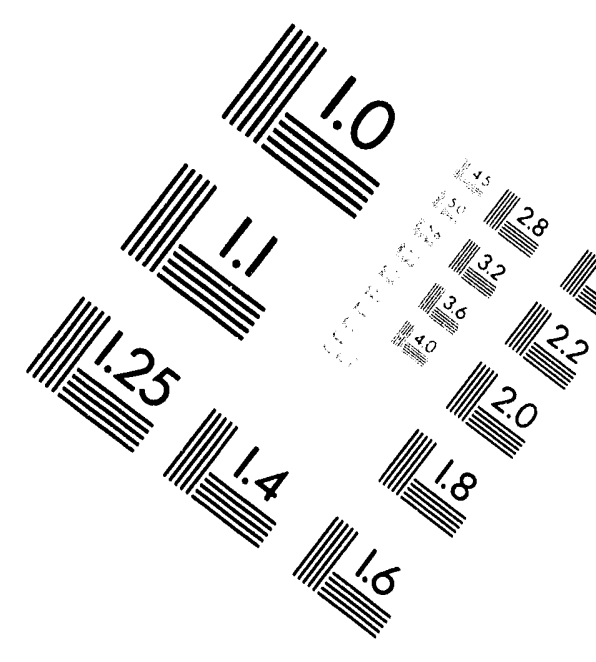

Centimeter

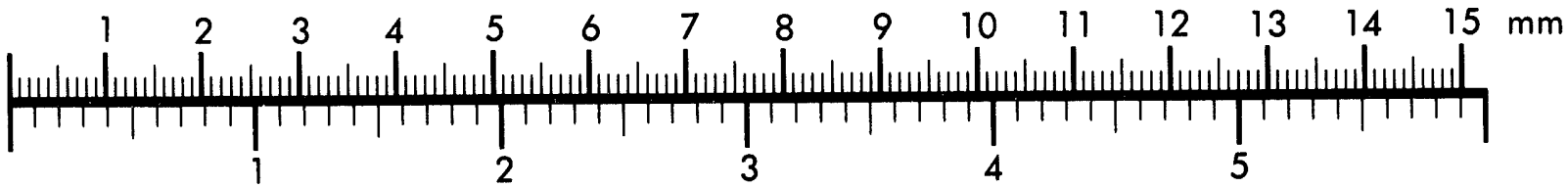

Inches
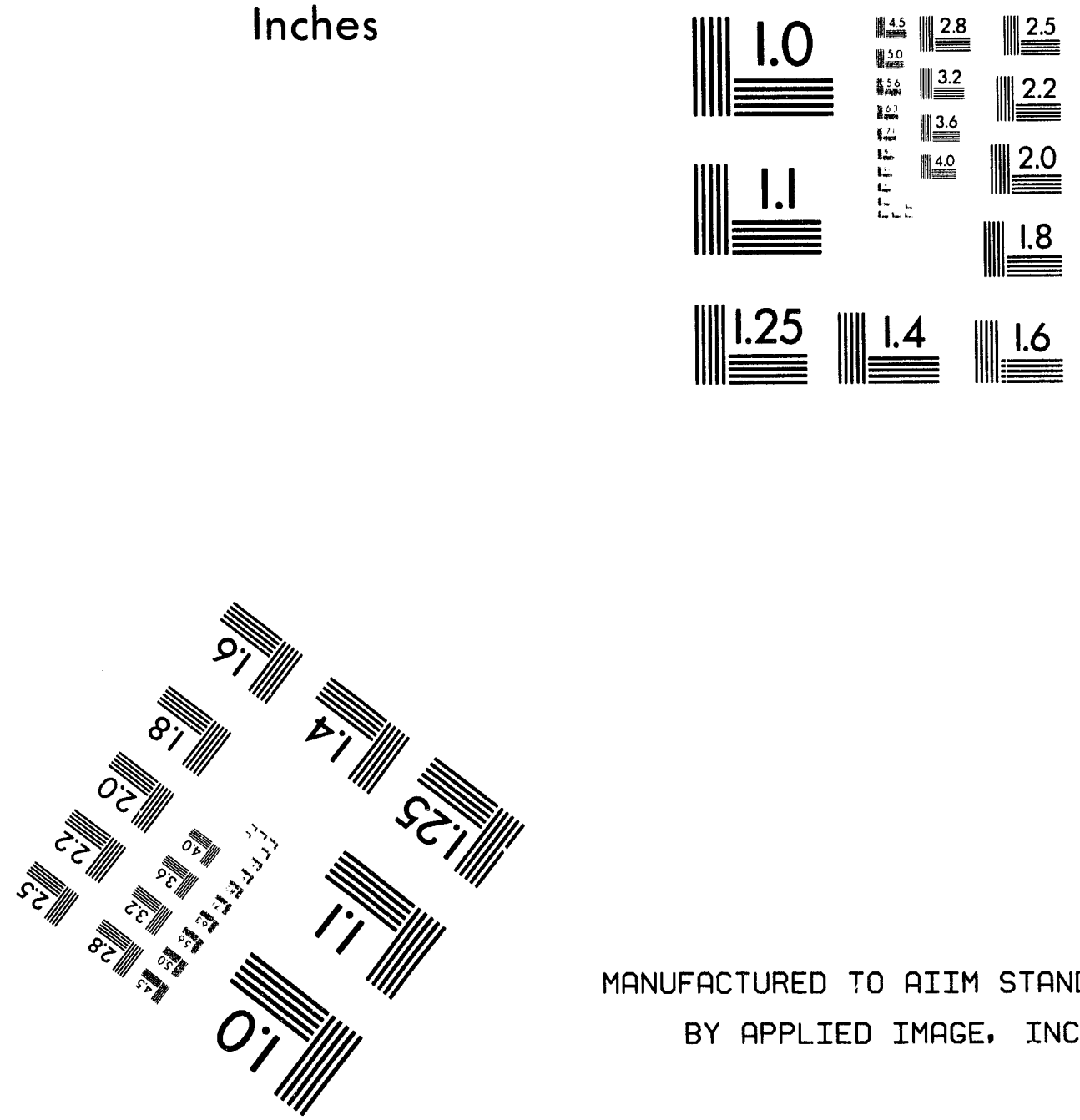

MANUFACTURED TO AIIM STANDARDS

BY APPLIED IMAGE, INC.

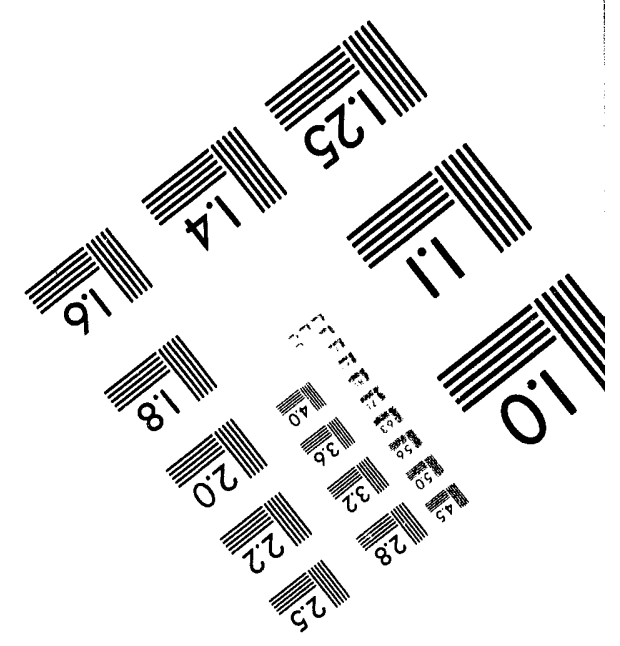



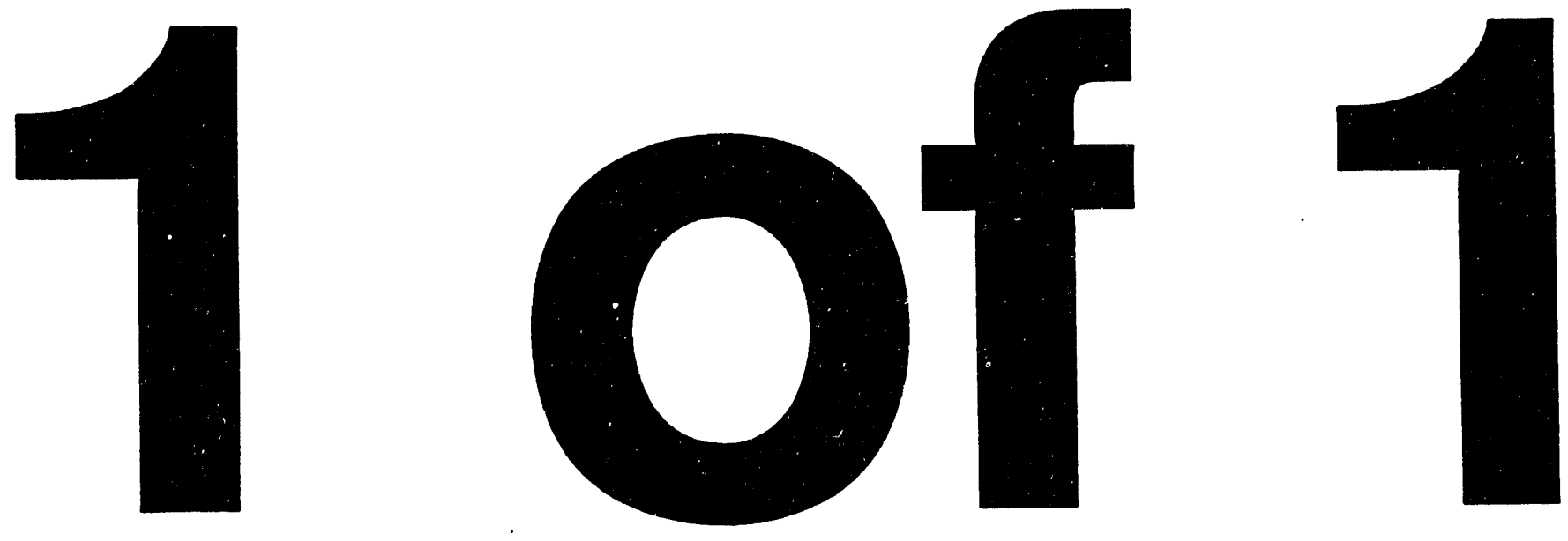


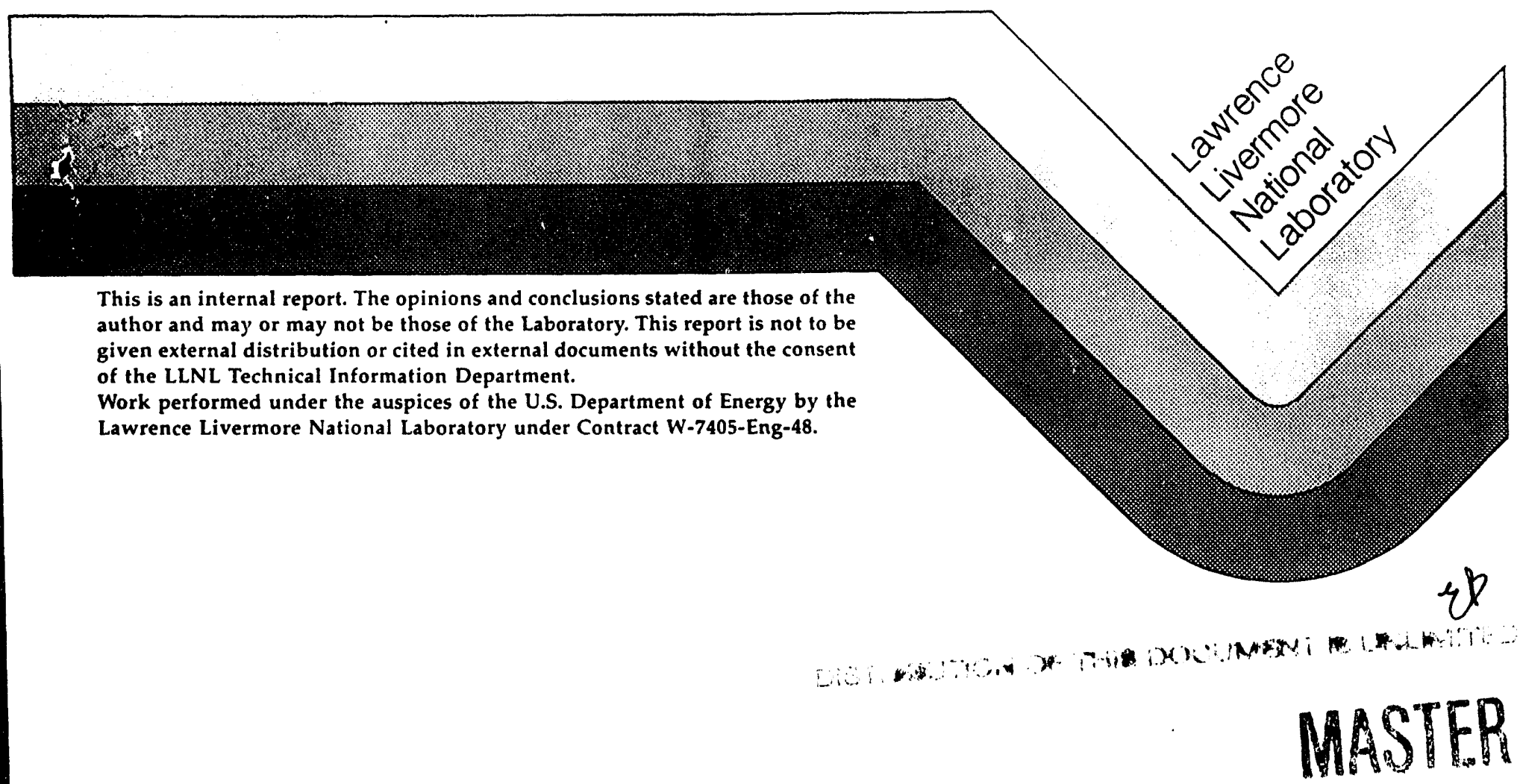




\section{DISCLAIMER}

This document was prepared as an account of work sponsored by an agency of the United States Government. Neither the United States Government nor the University of California nor any of their employees, makes any warranty, express or implied, or assumes any legal liability or responsibility for the accuracy, completeness, or usefulness of any information, apparatus, product, or process disclosed, or represents that its use would not infringe privately owned rights. Reference herein to any specific commercial products, process, or service by trade name, trademark, manufacturer, or otherwise, does not necessarily constitute or imply its endorsement, recommendation, or favoring by the United States Government or the University of California. The views and opinions of authors expressed herein do not necessarily state or reflect those of the United States Government or the University of California, and shall not be used for advertising or product endorsement purposes.

This report has been reproduced directly from the best available copy.

Available to DOE and DOE contractors from the

Office of Scientific and Technical Information

P.O. Box 62, Oak Ridge, TN 37831

Prices available from (615) 576-8401, FTS 626-8401

Available to the public from the

National Technical Information Service

US. Department of Commerce

5285 Port Royal Rd.

Springfield, VA 22161 


\title{
Base Hydrolysis of HMX/DMSO Solutions
}

\author{
Philip F. Pagoria \\ Energetic Materials Center \\ Lawrence Livermore National Laboratory \\ Livermore, CA 94550 \\ March 15, 1994
}

We investigated the decomposition of HMX or PBX-9404 as a $25 \%$ solution in DMSO by treatment with aqueous base solutions. We investigated two concentrations of $\mathrm{NaOH}$ solutions, $40 \% \mathrm{NaOH}$ and $2 \mathrm{~N} \mathrm{NaOH}$. The method we chose to follow the decomposition was by ${ }^{1} \mathrm{H}$-nmr spectroscopy, watching the disappearance of the $-\mathrm{CH}_{2}$ - absorbence of $\mathrm{HMX}$ at $6.2 \mathrm{ppm}$. The $40 \%$ $\mathrm{NaOH}$ solution is initially immiscible with the DMSO solution but becomes miscible as it reacts. The reaction is exothermic with recorded temperatures after mixing reaching $90^{\circ} \mathrm{C}$. The mixture does foam somewhat but this can be controlled by slowing down the stirring speed which reduces the foaming. The $2 \mathrm{~N} \mathrm{NaOH}$ solution is miscible with the HMX/DMSO solution but upon mixing the HMX is precipitated by the water present in the base solution. The mixing of the solutions is much less exothermic and the decomposition is slower than the $40 \% \mathrm{NaOH}$ solution so the mixture is heated at $60^{\circ} \mathrm{C}$ for $1 \mathrm{~h}$ to facilitate the decomposition.

Procedure: A $3 \mathrm{~g}$ (10.1 mmol) sample of HMX or PBX-9404 was dissolved in $12 \mathrm{~mL}$ of DMSO-d 6 . A $40 \% \mathrm{NaOD} / \mathrm{D}_{2} \mathrm{O}$ solution $(6.1 \mathrm{~mL})(61$ $\mathrm{mmol}$ ) was added and the biphasic mixture was stirred at room temperature. Upon stirring the mixture became homogenous, foamed slightly (this may be 
controlled by slowing down the stirring which reduces the foaming), and warmed to $90^{\circ} \mathrm{C}$. The mixture was stirred $10 \mathrm{~min}$ and an ${ }^{1} \mathrm{H}-\mathrm{nmr}$ spectrum was taken of the still warm mixture. The ${ }^{1} \mathrm{H}-\mathrm{nmr}$ spectrum indicated that all the $\mathrm{HMX}$ was decomposed (loss of peak at $6.2 \mathrm{ppm}$ which corresponds to the $-\mathrm{CH}_{2}$ protons of HMX). The ${ }^{1} \mathrm{H}-\mathrm{nm}$ spectrum shows a peak at $8.5 \mathrm{ppm}$ which we have assigned to sodium formate. It may be generated from the HMX decomposition by the reaction of formaldehyde with excess base present. The final solution is a thick, red, viscous suspension.

This procedure can also be done using $60 \mathrm{mmol}$ of a $2 \mathrm{~N} \mathrm{NaOH}$ solution $(30 \mathrm{~mL})$ and heating the solution at $60^{\circ} \mathrm{C}$ for $1 \mathrm{~h}$. Upon mixing the DMSO and base solutions a slurry is formed. After $1 \mathrm{~h}$ a clear yellow solution is realized. The final ${ }^{1} \mathrm{H}$-nmr spectrum is almost identical to the one obtained from the decomposition using the $40 \% \mathrm{NaOD}$ solution. 

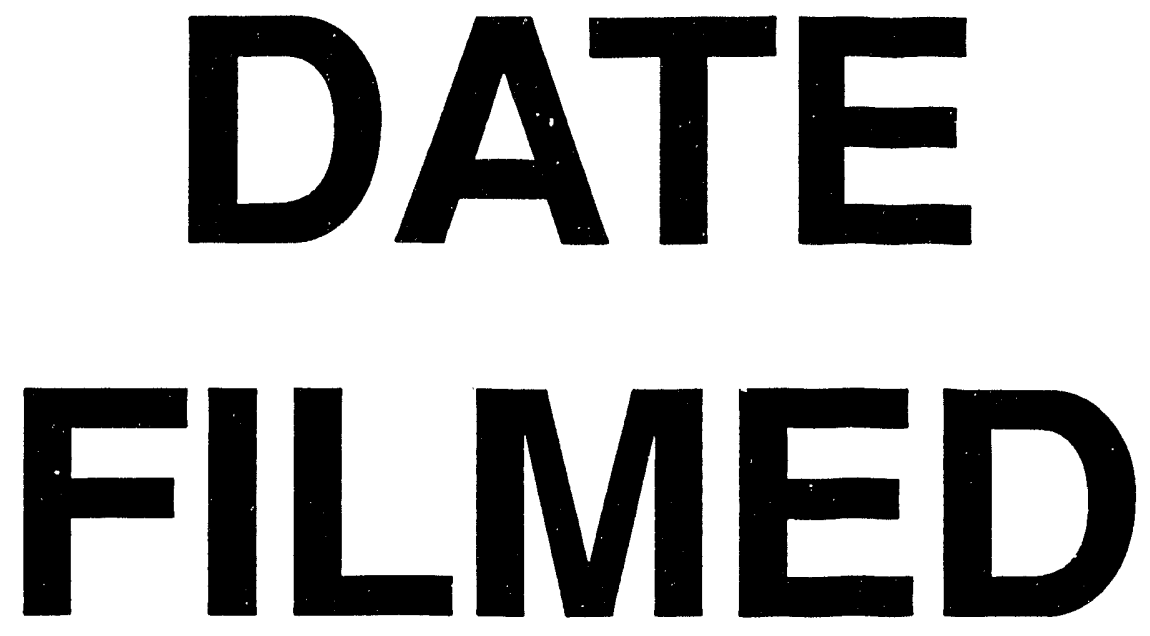

$8 / 25 / 94$
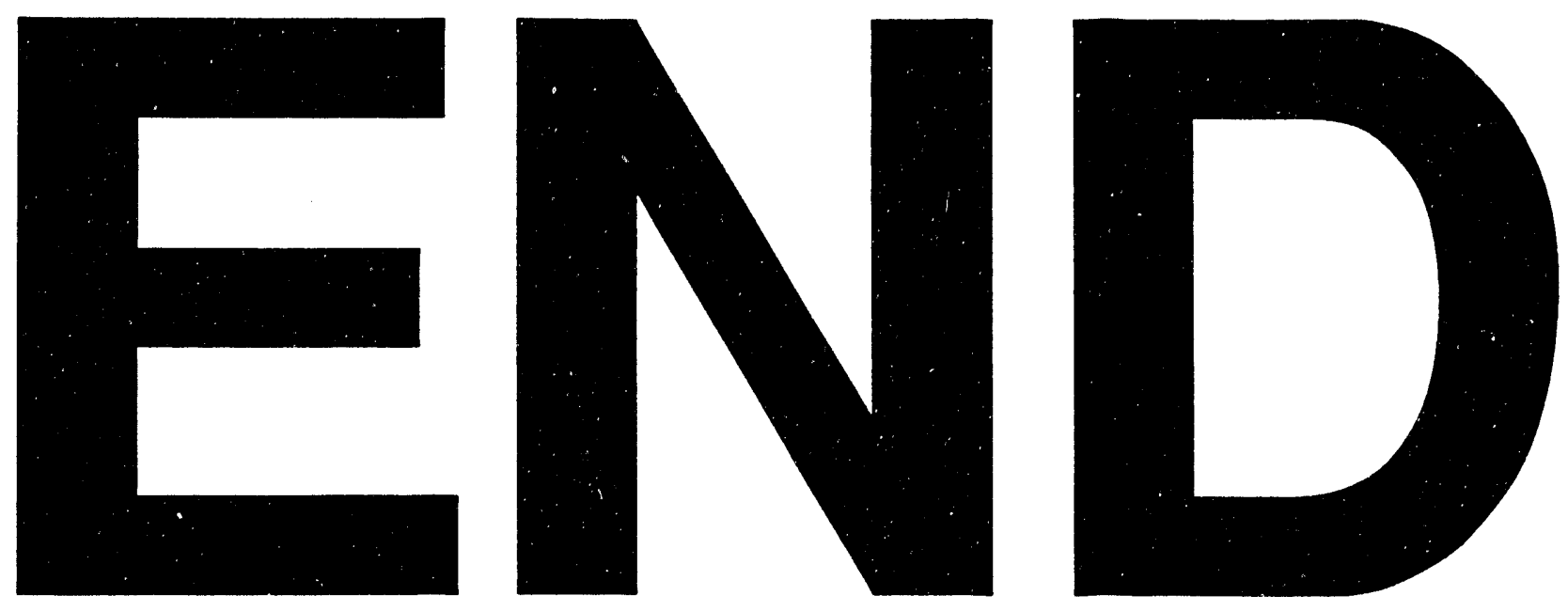


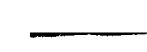

